\title{
Carboxycinnamic Acid Bishydroxamide
}

National Cancer Institute

\section{Source}

National Cancer Institute. Carboxycinnamic Acid Bishydroxamide. NCI Thesaurus. Code C1797.

A hybrid polar compound that induces terminal differentiation and/or apoptosis in various transformed cells. It is an inhibitor of histone deacetylase. 